\title{
Enhanced efficiency in HA removal by electrocoagulation through optimizing flocs properties: Role of current density and $\mathrm{pH}$
}

\author{
Chengzhi Hu ${ }^{a}$, Jingqiu Sun ${ }^{\mathrm{a}, \mathrm{b}}$, Shuqing Wang ${ }^{\mathrm{a}}$, Ruiping Liu ${ }^{\mathrm{a}, *}$, Huijuan Liu ${ }^{\mathrm{c}}$, Jiuhui $\mathrm{Qu}^{\mathrm{a}}$ \\ a Key Laboratory of Drinking Water Science and Technology, Research Center for Eco-Environmental Sciences, Chinese Academy of Sciences, Beijing 100085, China \\ ${ }^{\mathrm{b}}$ University of Chinese Academy of Sciences, Beijing 100049, China \\ ' State Key Laboratory of Environmental Aquatic Chemistry, Research Center for Eco-Environmental Sciences, Chinese Academy of Sciences, Beijing 100085, China
}

\section{A R T I C L E I N F O}

\section{Article history:}

Received 16 May 2016

Received in revised form 13 October 2016

Accepted 14 November 2016

Available online 15 November 2016

\section{Keywords:}

Electrocoagulation

Aluminum

Flocs

Water treatment

\begin{abstract}
A B S T R A C T
The performance of electrocoagulation (EC) significantly depends on flocs properties that could be improved through regulating electrochemical parameters. However, little information has been collected to date regarding the relationship between flocs characteristics and electrochemical parameters. In this study, the influences of $\mathrm{pH}$ and current density $(j)$ were investigated to characterize the flocs generated from EC process with aluminum anode. The results indicated that higher $j$ performed better on HA removal due to a larger Al dosage. A highest efficiency in HA removal by EC process occurred at weak acidic range, where the flocs presented a stronger adsorption ability. Higher $j$ and higher water $\mathrm{pH}$ led to a larger flocs size. The EC time to form the largest flocs was consistent with that to reach zero point charge, where surface charge favors the aggregation of $\mathrm{Al}(\mathrm{OH})_{3}$ precursors to form large flocs. Flocs strength was positively correlated with applied $j$ and negatively correlated with water $\mathrm{pH}$. The flocs generated with low applied $j$ and at low initial $\mathrm{pH}$ had a higher value of BET surface area and a more porous surface structure.
\end{abstract}

(c) 2016 Elsevier B.V. All rights reserved.

\section{Introduction}

Electrocoagulation (EC) has been considered as an alternative method compared with conventional chemical coagulation (CC) in water treatment. The advantages of EC include a compact treatment facility, relatively low cost, less sludge production, minimum requirement of chemicals, and the possibility of complete automation [1-4]. It has been intensively investigated and successfully applied for heavy metals [5,6], organic compounds [7-9], anions $[4,10]$, and particulates $[11,12]$ removal from drinking water and wastewater.

The properties of flocs, such as size, structure and strength, have a significant effect on the subsequent separation process of sedimentation and/or filtration [13,14], and thus are crucial to the efficiency of both CC and EC process. The active coagulant species are in-situ and continually generated with the electrolytic oxidation of an appropriate anode, which differs from CC process in which metal salts are added by one time dosage. The results of Harif et al. [15], indicated that EC could generate relatively porous and fragile flocs compared with CC. The removal mechanism of EC has been proposed that is in compliance with the physico- chemical properties of flocs [16,17]. Comparing with CC, the morphology and structure of flocs generated from EC process was rarely explored. Electrochemical parameters and solution chemical properties would no doubt produce significant influence on flocs properties during EC process.

For the flocculation mechanism of EC, applied current density $(j)$ is considered to have a twofold effect because it both controls the dissolution of metal anode into metal ion and also causes the electrolysis of water as a result of which the $\mathrm{pH}$ rises rapidly. The mechanisms in EC are differed as the dosage and $\mathrm{pH}$ increase at each given time throughout the whole process till the stop of current. Factors such as $\mathrm{pH}$ or coagulant dosage have the primary influence on the formation of the active mononuclear, polynuclear or amorphous species $[18,19]$, and then greatly influence the properties of flocs morphology and structure [20,21].

In this study, the influences of $\mathrm{pH}$ and $j$ were investigated to characterize the flocs generated from EC process with aluminum anode. The properties of flocs have been clarified with size distribution, Zeta potential and microcosmic appearance. The relations between the flocs morphology and structure and the removal of natural organic material (NOM) have also been discussed.

\footnotetext{
* Corresponding author.

E-mail address: liuruiping@rcees.ac.cn (R. Liu).
} 


\section{Materials and methods}

\subsection{Chemicals and apparatus}

A stock solution of 1000 ppm humic acid (HA, Sigma-Aldrich) was prepared by dissolving $1 \mathrm{~g}$ of $\mathrm{HA}$ in $0.1 \mathrm{~N} \mathrm{NaOH}$ and diluted to $1 \mathrm{~L}$ with deionized water and stored in a cold room and in a dark glass bottle after mixing well. Kaolin (Sinopharm) was used as the standard particles. A certain amount of kaolin was added in $1 \mathrm{~L}$ deionized water, with $\mathrm{pH}$ adjusted to 7.5 , and mixed by a magnetic stirrer for $1 \mathrm{~h}$. After settlement of $12 \mathrm{~h}$, the upper suspensions were collected to prepare a stock solution of kaolin. The particle concentration was determined by weight analysis method. Water samples were synthesized by spiking the stock solution of HA and kaolin into deionized water containing $0.05 \mathrm{M} \mathrm{NaCl}$ and $0.5 \mathrm{mM} \mathrm{NaHCO}$. The initial dissolved organic carbon (DOC) and turbidity of water samples were $5 \mathrm{mg} / \mathrm{L}$ and $8.3 \mathrm{NTU}$, respectively.

EC experiments have been carried out in an EC cell. Al electrodes were used as the anode and cathode. The electrodes were square in shape with a geometric area of $55 \mathrm{~cm}^{2}$ $(6.5 \mathrm{~cm} \times 8.45 \mathrm{~cm})$ each and with an electrode gap of $10 \mathrm{~mm}$. Electricity was supplied by a DC power supply (DH1720A-6, Dahua, China). Before each experiment, the electrodes were polished with sandpaper to remove the scale build-up and then dipped in a $1.3 \mathrm{~mol} / \mathrm{L} \mathrm{HCl}$ solution for $10 \mathrm{~min}$, and then finally cleaned with successive rinses of deionized water. During each test run, the synthesized water sample of $1.0 \mathrm{~L}$ was placed into the cell. The initial $\mathrm{pH}$ of water samples was adjusted by adding $0.2 \mathrm{~mol} / \mathrm{L} \mathrm{NaOH}$ or $0.05 \mathrm{~mol} / \mathrm{L} \mathrm{HCl}$. After that, the magnetic stirrer was turned on and set at $100 \mathrm{rpm}$.

\subsection{Flocs size, surface charge and morphology characterization}

A laser diffraction instrument (Mastersizer 2000, Malvern, UK) was used to measure dynamic floc size $\left(d_{50}\right)$ as the EC process proceeded. Flocs size was monitored by drawing water through the optical unit of the Mastersizer and back into the EC cell by a peristaltic pump. Size measurements were taken every half a minute for the duration of the EC process and logged onto a PC.

Surface potential of flocs that were sampled during EC process was characterized by Zeta potential analyzer (DelsaNano C, Beckman, USA). The flocs samples, which were separated from water with a refrigerating centrifuge (J2-HS, Beckman, USA) and subsequently dried by a vacuum-freeze dryer (FD-1A, BoYikang, China) for $48 \mathrm{~h}$, were analyzed by field emission scanning electron microscopy (FE-SEM, Hitach, Japan). BET surface area, pore diameter, and pore volume of the dried flocs samples were determined by a surface analyzer (NOVA 4000, Quantachrome, USA) with $\mathrm{N}_{2}$ as the adsorbate at $90 \mathrm{C}$ in the relative pressure range from about 105 to 0.95 .

\subsection{Flocs strength characterization}

The growth, breakage and regrowth of flocs during the EC process were investigated to evaluate the effect of $\mathrm{pH}$ and $j$ on flocs strength. The assessment method is similar to that of Zhu et al. [22]. The flocs grew in the slow stirring of $100 \mathrm{rpm}$ for $10 \mathrm{~min}$, and then was suddenly exposed to a 5 min strong stirring of $500 \mathrm{rpm}$ for breakage, after which regrowth was undertaken at $100 \mathrm{rpm}$ for $15 \mathrm{~min}$. Dynamic flocs size $\left(\mathrm{d}_{50}\right)$ was monitored in the whole procedure as described in Section 2.2. Size measurements were taken every $40 \mathrm{~s}$.

A size ratio method is used here with an index (strength factor) to express the strength of particle flocs, i.e.,
Strength Factor $=\frac{\mathrm{d}_{2}}{\mathrm{~d}_{1}} \times 100$

where $d_{1}$ and $d_{2}$ are the mean sizes of the flocs before and after the shear breakage, respectively. A higher value of the strength factor indicates a higher ability of the flocs to resist breakage when exposed to an elevated fluid shear.

When the shear intensity was reduced after the breakage phase, re-flocculation of the flocs could take place. A reversibility factor is used here to measure the re-flocculation potential of the flocs when the shear is returned to its original level. A modified size ratio approach may be applied to calculate the reversibility (Recovery Factor) by

Recovery Factor $=\frac{\mathrm{d}_{3}-\mathrm{d}_{2}}{\mathrm{~d}_{1}-\mathrm{d}_{2}} \times 100$

where $d_{3}$ is the mean size of the particle flocs after re-flocculation at the original shear rate. A higher Recovery Factor suggests a greater flocculation and regrowth capability of the flocs after the shear breakage.

\subsection{HA removal by EC and flocs adsorption}

$\mathrm{UV}_{254}$ was measured to evaluate the performance on HA removal by EC. The initial $U_{254}$ value and turbidity of the synthesized water samples were $0.36 \mathrm{~cm}^{-1}$ and $8.3 \mathrm{NTU}$, respectively. During EC process, $15 \mathrm{~mL}$ water sample was taken into test tube at certain time, after a $30 \mathrm{~min}$ settling period the supernatants were collected to measure residual turbidity using a $\mathrm{HACH}$ $2100 \mathrm{~N}$ turbidity meter. The filtrates by $0.45 \mu \mathrm{m}$ pore size membrane filter were tested for $U_{254}$ with a UV-visible spectrometer (U-3010, Hitachi, Japan).

Adsorption experiments were initiated to evaluate HA removal by adsorption on preformed $\mathrm{Al}$ hydroxide flocs in $\mathrm{EC}$ process. In the water samples without $\mathrm{HA}$, Al hydroxide flocs performed during EC process. After which, a certain amount of HA was added into the preformed flocs suspensions and then the slow stirring (300 rpm) was maintained for 2 min to make the solution well distributed. And then turn stirring speed to $100 \mathrm{rpm}$ to allow the HA to be adsorbed. After the adsorption step, the settling step was applied. The experimental condition (e.g. initial pH and $j$ etc.) of adsorption was same as that of EC. The performance of HA removal by flocs adsorption was compared with that by EC.

\section{Results and discussion}

\subsection{Surface charge characterization}

The zeta potential of flocs gradually increased as a function of EC time (Fig. 1). During EC process, dissolved $\mathrm{Al}$ hydrolyzes into monomeric $\left(\mathrm{Al}(\mathrm{OH})^{2+}, \mathrm{Al}(\mathrm{OH})_{2}^{+}\right)$, dimeric $\left(\mathrm{Al}_{2}(\mathrm{OH})_{2}^{4+}\right)$ species, and medium polymer species (i.e. $\mathrm{AlO}_{4} \mathrm{Al}_{12}(\mathrm{OH})_{24}\left(\mathrm{H}_{2} \mathrm{O}\right)_{12}^{7+}, \mathrm{Al}_{13}$ ), etc. [23]. These positive $\mathrm{Al}$ species neutralizes the negative charge of HA and kaolin, and flocculate to form flocs. The dosage of positive Al species increased with increasing EC time, which contributed the gradual rise of flocs charge. Surface potential stabilized a certain value after charge reversal, where the negative surface charge on flocs was completely neutralized. Surface potential of flocs was positively correlated with the applied $j$ (Fig. 1a). The zeta potential reached zero point charge (ZPC) at pH 7.7 about 5 min with the $j$ of $50 \mathrm{~A} / \mathrm{m}^{2}$, while surface charge was still negative at $30 \mathrm{~min}$ with the $j$ of $2 \mathrm{~A} / \mathrm{m}^{2}$. According to the theoretical equation of dissolved $\mathrm{Al}$ concentration (Eq. (3)), a higher Al dosage can be obtained if a larger $\mathrm{j}$ was applied in EC process. Thus the higher $j$ was used; the more positive $\mathrm{Al}$ species are available. 


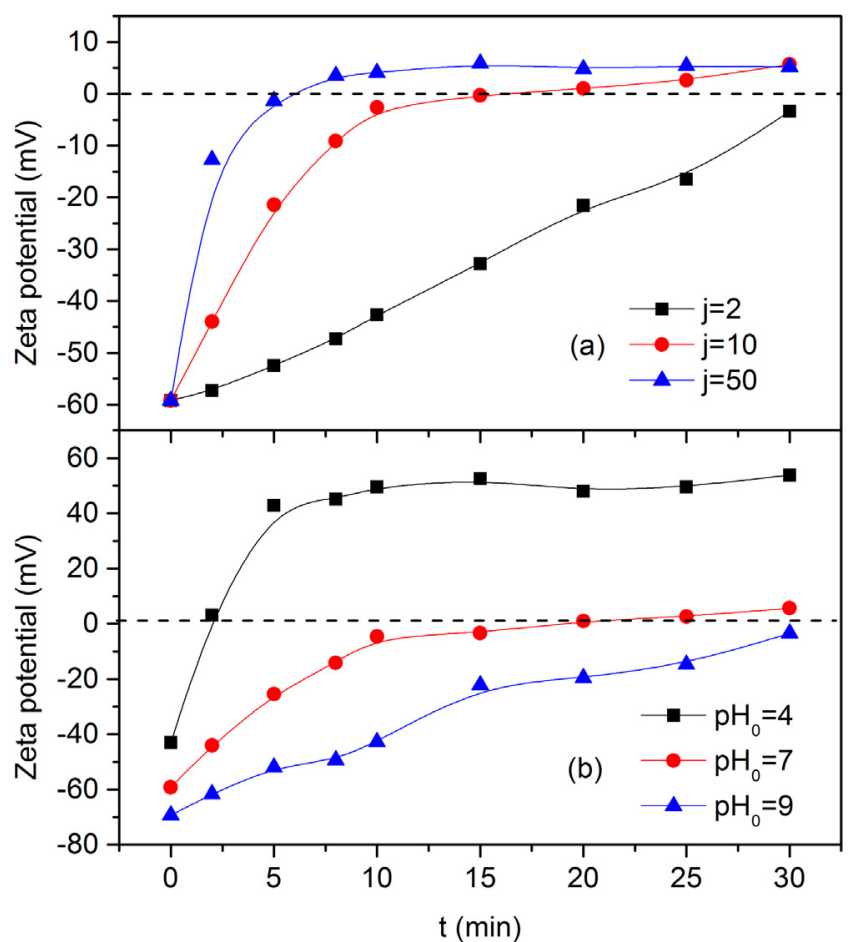

Fig. 1. The effect of (a) applied $j$ and (b) initial $\mathrm{pH}$ on the Zeta potential of flocs.

$[\mathrm{Alg} / \mathrm{L}]=\frac{\mathrm{nItM}_{\mathrm{Al}}}{\mathrm{ZFV}}$

where $n$ is cells number $(n=1)$, $I$ is current $(A), t$ is reaction time $(s)$, $\mathrm{Z}$ is valence ( 3 for aluminum), $\mathrm{M}_{\mathrm{Al}}$ is molecular weight of aluminum ( $26.98 \mathrm{~g} / \mathrm{mol}), \mathrm{F}$ is faraday constant $(96487 \mathrm{C} / \mathrm{mol}), \mathrm{V}$ is solution volume $(\mathrm{V}=1 \mathrm{~L})$.

Fig. 1b shows that initial $\mathrm{pH}$ value was negatively correlated with the zata potential of flocs. Within $2 \mathrm{~min}$ at $\mathrm{pH}_{0}=4.0$, charge reversal occurred and zeta potential acquiring positive values. This was indicative of more positively charged hydrolyzed species formation following aluminum anodic dissolution. Stabilization occurred at $20 \mathrm{~min}$ for $\mathrm{pH}_{0} 7.0$ as $\mathrm{pH}$ condition became favorable for $\mathrm{Al}(\mathrm{OH})_{3}$ precipitation. While for the $\mathrm{pH}_{0} 9.0$, the zeta potential was still negative till $30 \mathrm{~min}$. For $\mathrm{pH} 9$, more $\mathrm{OH}^{-}$ions was available to form anionic $\mathrm{Al}$ species such as $\mathrm{Al}(\mathrm{OH})_{4}^{-}$and $\mathrm{Al}(\mathrm{OH})_{5}^{2-}$, so the zeta potential was still negative.

Fig. 2 shows that water $\mathrm{pH}$ consecutively changed during the $30 \mathrm{~min}$ in EC process. For the solutions with initial $\mathrm{pH} 4$ and 7 (Fig. 2a and b), the increase in pH can be explained by the formation of $\mathrm{OH}^{-}$from the reduction of $\mathrm{H}^{+}$or $\mathrm{H}_{2} \mathrm{O}$ on the surface of the cathode. (Eqs. (4) and (5)). $\mathrm{Al}^{3+}$ dissolved from anode (Eq. (6)) unites with part of $\mathrm{OH}^{-}$and underwent the processes of hydrolysis, polymerization, gelation and precipitation (Eq. (7)). It is noted that $\mathrm{pH}$ declined for the initial pH 9 (Fig. 2b), which could be ascribed to the consumption of $\mathrm{OH}^{-}$ions to form anionic $\mathrm{Al}$ species such as $\mathrm{Al}$ $(\mathrm{OH})_{4}^{-}$and $\mathrm{Al}(\mathrm{OH})_{5}^{2-}$. Comparing with alkaline condition, the higher zeta potential of flocs at acidic $\mathrm{pH}$ results from the higher $\mathrm{H}^{+}$concentration in solution. Moreover, water $\mathrm{pH}$ is a crucial factor to influence $\mathrm{Al}$ species distribution [24-26]. Water $\mathrm{pH}$ in the EC processed mainly located at weak acidic range ( $\mathrm{pH} 5-7$, Fig. 2b), where $\mathrm{Al}$ hydrolysates have a stronger ability of charge neutralization as more medium polymer species (such as $\mathrm{Al}_{13}$ and $\mathrm{Al}_{30}$ ) that have higher positive charge generate in solution. In the $\mathrm{EC}$ process with $50 \mathrm{~A} / \mathrm{m}^{2}$, water $\mathrm{pH}$ was highest among the applied $j$ (Fig. 2a), but the zeta potential of flocs was also highest (Fig. 1a). It is inconsistent with the results mentioned above about the influence of $\mathrm{pH}$ on

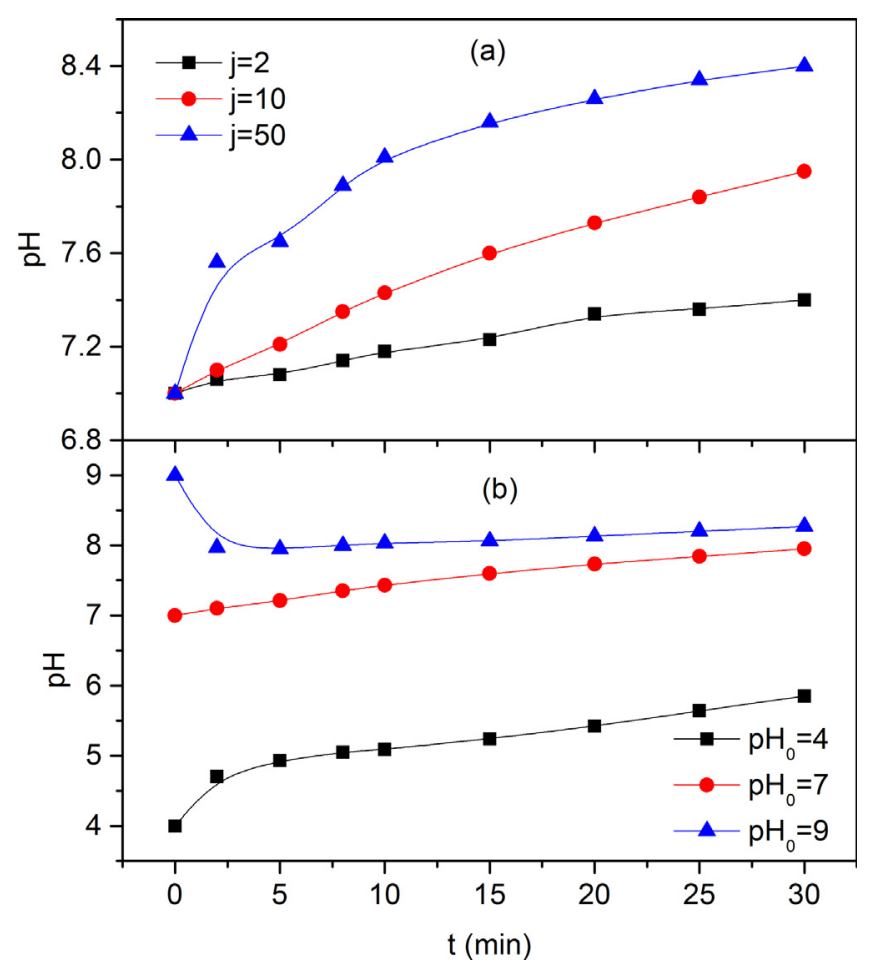

Fig. 2. The effect of (a) applied $j$ and (b) initial pH on pH changes during EC process.

flocs zeta potential, and maybe attribute to largest Al concentration obtained from the EC process with $50 \mathrm{~A} / \mathrm{m}^{2}$.

Cathode reaction : $2 \mathrm{H}^{+}+2 \mathrm{e}^{-} \rightarrow \mathrm{H}_{2}$

$2 \mathrm{H}_{2} \mathrm{O}+2 \mathrm{e}^{-} \rightarrow \mathrm{H}_{2}+2 \mathrm{OH}^{-}$

Anode reaction $: \mathrm{Al} \rightarrow \mathrm{Al}^{3+}+3 \mathrm{e}^{-}$

$$
\begin{aligned}
\mathrm{Al}^{3+}+4 \mathrm{OH}^{-} & \rightarrow \mathrm{Al}(\mathrm{OH})_{4}^{-}+\text {monomeric or dimeric } \mathrm{Al} \\
& \rightarrow \mathrm{Al}_{13} \text { or } \mathrm{Al}_{30} \text { polymer }+\mathrm{OH}^{-} \\
& \rightarrow \text { colloid and precipitated } \mathrm{Al}+\mathrm{OH}^{-} \\
& \rightarrow \mathrm{Al}(\mathrm{OH})_{3} \downarrow
\end{aligned}
$$

\subsection{Flocs size characterization}

Flocs size $\left(\mathrm{d}_{50}\right)$ in different $\mathrm{pH}$ condition and $j$ was monitored over the whole EC process. Fig. 3a indicated that higher $j$ resulted in a larger flocs size and a faster growth rate. The results of Fig. $3 \mathrm{~b}$ displayed that higher water $\mathrm{pH}$ led to a larger flocs size, but a slower growth rate especially in the primary period of EC process. Flocs size evolution vs time followed two consecutive stages: a stage of rapid growth at primary period then followed by a stage in which flocs size were close to a constant value. It is noted that, for the $d_{50}$ of $50 \mathrm{~A} / \mathrm{m}^{2}$ (Fig. 3a), the flocs size decreased after arriving maximal value at about $7 \mathrm{~min}$.

$\mathrm{Al}(\mathrm{OH})_{3}$ nucleation and precipitation would occur when the concentration of alumina reaches the critical saturation point. And the formation of $\mathrm{Al}(\mathrm{OH})_{3}$ precursor depends on $\mathrm{Al}$ dosage and water $\mathrm{pH}$ [27]. EC process could provide both high Al dosage and $\mathrm{pH}$ value with a high current density, resulted in more precursor of $\mathrm{Al}(\mathrm{OH})_{3}$. And that would provide more opportunities for the aggregation of precursors and subsequent formation of submicron precursors [28]. Surface charge is also a significant factor in formation of flocs by providing stable bonds between small particles 


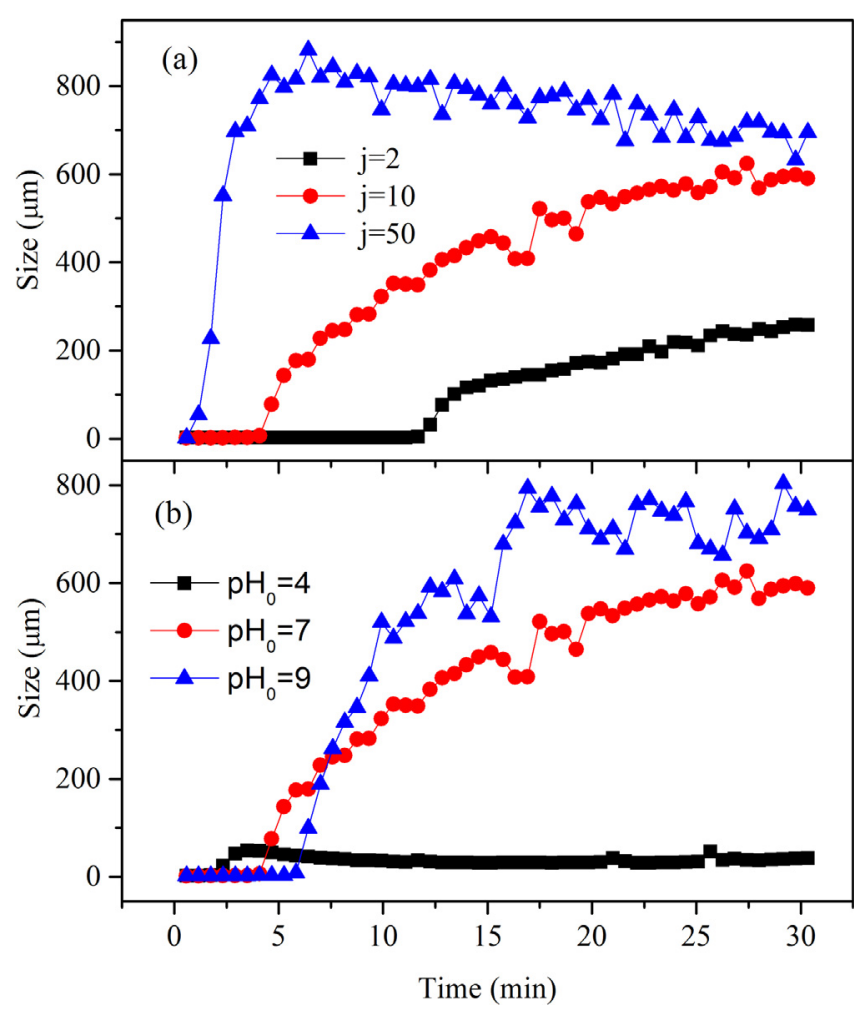

Fig. 3. Flocs sizes evolution within different (a) applied $j$ and (b) initial $\mathrm{pH}$ conditions.

[29]. From Figs. 1 and 3, regardless of the magnitude of applied $j$ and initial $\mathrm{pH}$, the time to form the largest flocs was consistent with that to reach ZPC. At the point of ZPC, electrostatic repulsive force among precursors was lowest, and such surface charge favors the aggregation of precursors to form large flocs. After which, the positive charge of flocs gradually increases, and thus electrostatic repulsive force among precursors augments, resulting in the decline of flocs size. High water $\mathrm{pH}$ implying large $\mathrm{OH}^{-}$concentration, it could accelerate the processes of Al hydrolysis, polymerization and precipitation, and thus contributes the formation of larger flocs size.

\subsection{Flocs structure and morphology analysis}

Fig. 4 shows the variation of flocs size during the hydrodynamic sequencing. The flocs size was immediately reduced following an increase in shear. A reversibility phenomenon in terms of flocs size was observed, as mentioned in previous studies $[22,30]$. When the shear decreased to its initial value, the broken flocs could collide with each other again to form the larger ones. However, it may be noticed that the formed flocs could not regrow to anywhere near their previous size. This may be attributed to the different flocculation mechanisms. Flocs formed by charge neutralization

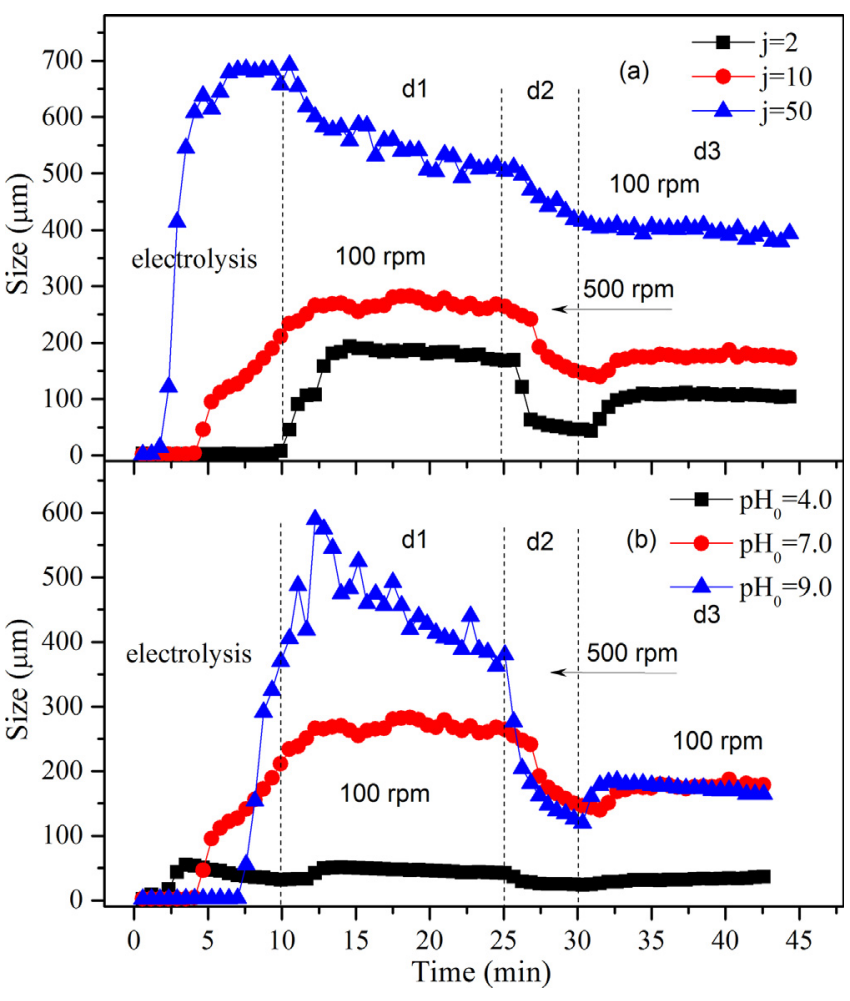

Fig. 4. The flocs breakage and regrow in different (a) applied $j$ and (b) initial pH conditions.

should give total recoverability. Thus, the irreversible breakage of the flocs was considered as evidence that the flocs formed in these systems were not dominated by pure charge neutralization mechanisms and were therefore held together by chemical rather than physical bonds, such as the combination of entrapment bridging and complexation with coagulant metal hydrolysis species [31].

Interpreting flocs growth and breakage can give important indications of floc strength [32]. Table 1 summarizes the values of the strength and recovery factor for the flocs under different $\mathrm{pH}$ and $j$. The flocs with $j=2 \mathrm{~A} / \mathrm{m}^{2}$ and $\mathrm{pH}_{0}=9$ were less able to resist the shearing condition, and their strength factor values were $23.16 \%$ and $26.67 \%$, respectively, lower than the flocs generated at other conditions. Flocs strength was positively correlated with applied $j$ and negatively correlated with water $\mathrm{pH}$. This may be explained by the flocs growth rate, which is coincident with the magnitude of flocs strength. The floc strengh is dependent upon the interparticle bonds between the components of the aggregates [32]. At the conditions of high applied $j\left(50 \mathrm{~A} / \mathrm{m}^{2}\right)$ and low initial $\mathrm{pH}\left(\mathrm{pH}_{0}=4\right)$, with a faster growth rate, the flocs are difficult to be broken up because there are floc precursors containing more effective $\mathrm{Al}$ for the flocs to stay firm. The flocs with $j=2 \mathrm{~A} / \mathrm{m}^{2}$ and $\mathrm{pH}_{0}=4$ recovered best after the breakage, and their recovery factor were $52.50 \%$ and $44.18 \%$, respectively. Lower applied $j$ and water $\mathrm{pH}$ favored the flocs recoverability, which can be ascribed to the coag-

Table 1

Strength and recovery factors of flocs on different initial $\mathrm{pH}$ and applied $\mathrm{j}$.

\begin{tabular}{|c|c|c|c|c|c|c|}
\hline Conditions & & $\mathrm{d}_{1}(\mu \mathrm{m})$ & $\mathrm{d}_{2}(\mu \mathrm{m})$ & $\mathrm{d}_{3}(\mu \mathrm{m})$ & Strength factor (\%) & Recovery factor (\%) \\
\hline \multirow[t]{3}{*}{$\mathrm{pH}=7$} & $j=2$ & 190 & 44 & 108.5 & 23.16 & 44.18 \\
\hline & $j=10$ & 281 & 140 & 180 & 49.8 & 28.37 \\
\hline & $j=50$ & 550 & 450 & 400 & 81.82 & \\
\hline \multirow[t]{3}{*}{$j=10 \mathrm{~A} / \mathrm{m}^{2}$} & $\mathrm{pH}_{0}=4$ & 44 & 24 & 34.5 & 54.54 & 52.50 \\
\hline & $\mathrm{pH}_{0}=7$ & 281 & 140 & 180 & 49.8 & 28.37 \\
\hline & $\mathrm{pH}_{0}=9$ & 450 & 120 & 176.5 & 26.67 & 17.12 \\
\hline
\end{tabular}


Table 2

Surface characteristics of $\mathrm{Al}$ floc generated in EC process with different initial $\mathrm{pH}$ and applied $j$.

\begin{tabular}{|c|c|c|c|c|c|c|}
\hline \multirow[t]{2}{*}{ Characteristics } & \multicolumn{3}{|l|}{$\mathrm{pH}_{0}=7.0$} & \multicolumn{3}{|c|}{$j=50 \mathrm{~A} / \mathrm{m}^{2}$} \\
\hline & $j=10 \mathrm{~A} / \mathrm{m}^{2}$ & $j=50 \mathrm{~A} / \mathrm{m}^{2}$ & $j=100 \mathrm{~A} / \mathrm{m}^{2}$ & $\mathrm{pH}_{0}=4.0$ & $\mathrm{pH}_{0}=7.0$ & $\mathrm{pH}_{0}=9.0$ \\
\hline BET surface area $\left(\mathrm{m}^{2} / \mathrm{g}\right)$ & 196.86 & 129.35 & 108.46 & 256.45 & 129.35 & 90.61 \\
\hline BJH Adsorption average pore diameter (nm) & 9.29 & 3.36 & 3.00 & 10.02 & 3.36 & 3.15 \\
\hline
\end{tabular}
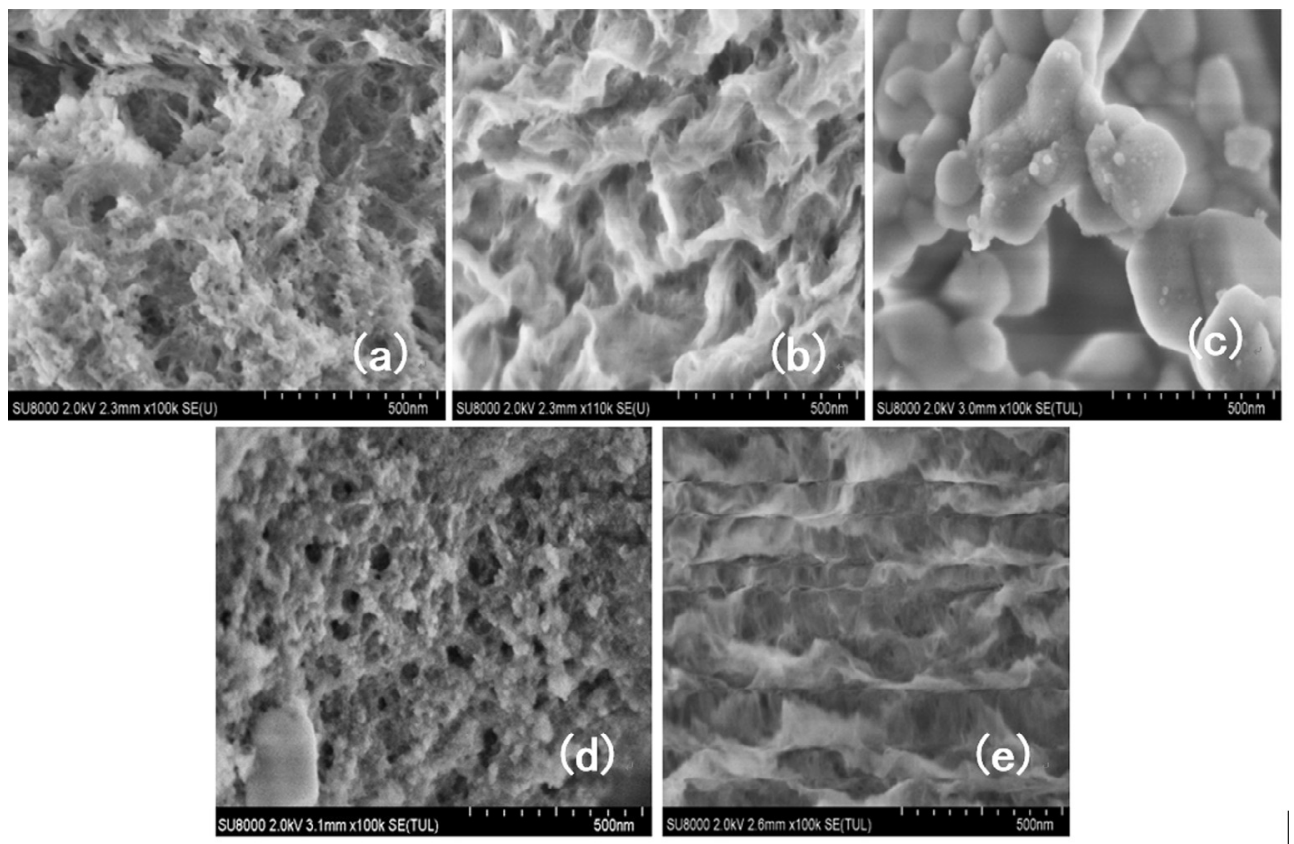

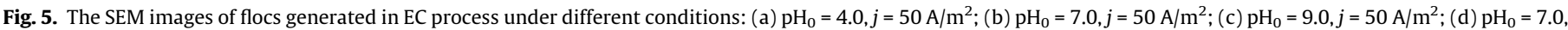
$j=10 \mathrm{~A} / \mathrm{m}^{2}$; (e) $\mathrm{pH}_{0}=7.0, j=100 \mathrm{~A} / \mathrm{m}^{2}$.

ulation mechanism as mentioned above. Generally, charge neutralization is the dominant coagulation mechanism at low coagulant dosage and low water $\mathrm{pH}$, while sweep coagulation mainly occurs at a high coagulant dosage and high water $\mathrm{pH}$ [33].

As shown in Table 2 , the flocs generated with low applied $j$ $\left(10 \mathrm{~A} / \mathrm{m}^{2}\right)$ and at low initial $\mathrm{pH}(\mathrm{pH} 4)$ had a higher value of BET surface area and a more porous surface structure. The BET surface area of the flocs generated with $10 \mathrm{~A} / \mathrm{m}^{2}$ and at $\mathrm{pH} 4$ were $196.86 \mathrm{~m}^{2} / \mathrm{g}$ and $256.45 \mathrm{~m}^{2} / \mathrm{g}$, respectively, while the values for $j=100 \mathrm{~A} / \mathrm{m}^{2}$ and $\mathrm{pH}_{0}=4$ were $108.46 \mathrm{~m}^{2} / \mathrm{g}$ and $90.61 \mathrm{~m}^{2} / \mathrm{g}$, respectively. The image of flocs generated at $\mathrm{pH}_{0}=4$ (Fig. 5a) presented a loose surface structure, while the image of flocs formed at $\mathrm{pH}_{0}=9$ showed a compact surface structure (Fig. 5c). The results of HESEM also revealed that the flocs surface at low $j\left(10 \mathrm{~A} / \mathrm{m}^{2}\right.$, Fig. 5d) was rougher than that at high $j$ (both $50 \mathrm{~A} / \mathrm{m}^{2}$, Fig. $5 \mathrm{~b}$ and $100 \mathrm{~A} / \mathrm{m}^{2}$, Fig. 5e), and it was consistent with the results of BET analysis. According to our previous results [23], low $j$ and weak acidic water conditions favored the formation of in-situ $\mathrm{Al}_{13}$ polymer. A lot of studies $[20,21]$ have demonstrated that the flocs generated from $\mathrm{Al}_{13}$ polymer are looser and more porous surface.

\subsection{Role of flocs in HA removal}

The removal of HA measured by $\mathrm{UV}_{254}$ was examined in different initial $\mathrm{pH}$ and applied $j$. As shown in Fig. 6a, higher $j$ performed better on HA removal due to a larger Al dosage. The residual $\mathrm{UV}_{254}$ for $50 \mathrm{~A} / \mathrm{m}^{2}$ closed to zero at $5 \mathrm{~min}$, while the EC process with $2 \mathrm{~A} /$ $\mathrm{m}^{2}$ needed about $30 \mathrm{~min}$ to attain the same $\mathrm{UV}_{254}$ removal. $\mathrm{UV}_{254}$

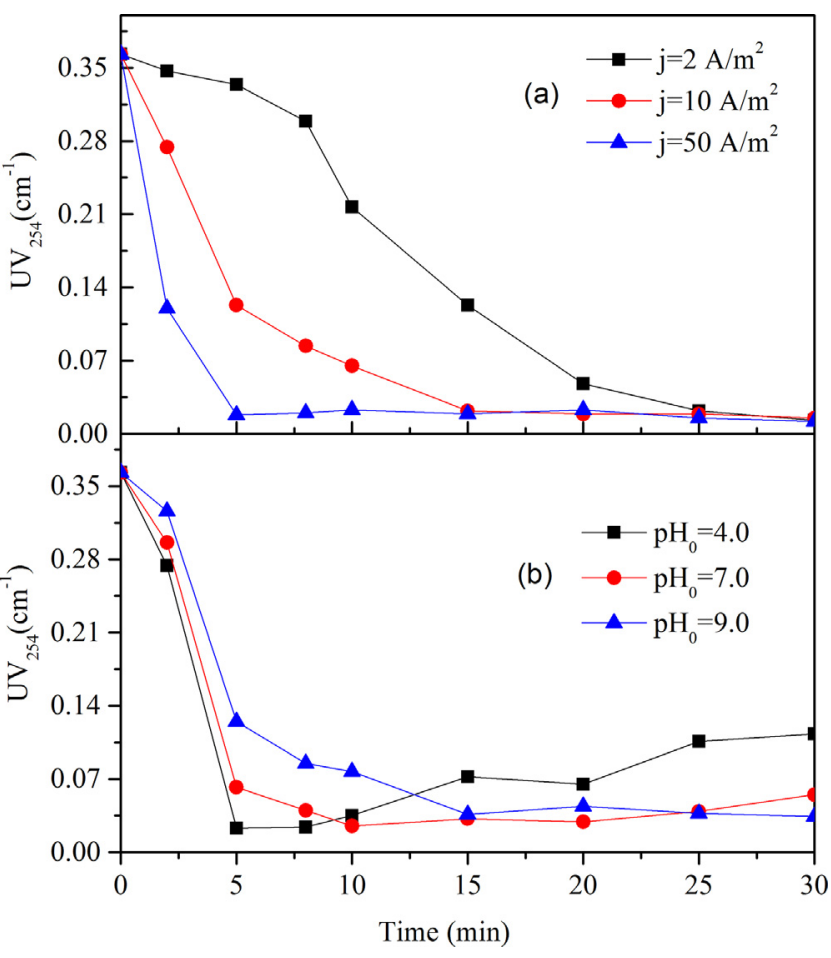

Fig. 6. The effect of (a) applied $j$ and (b) initial $\mathrm{pH}$ on HA removal. 


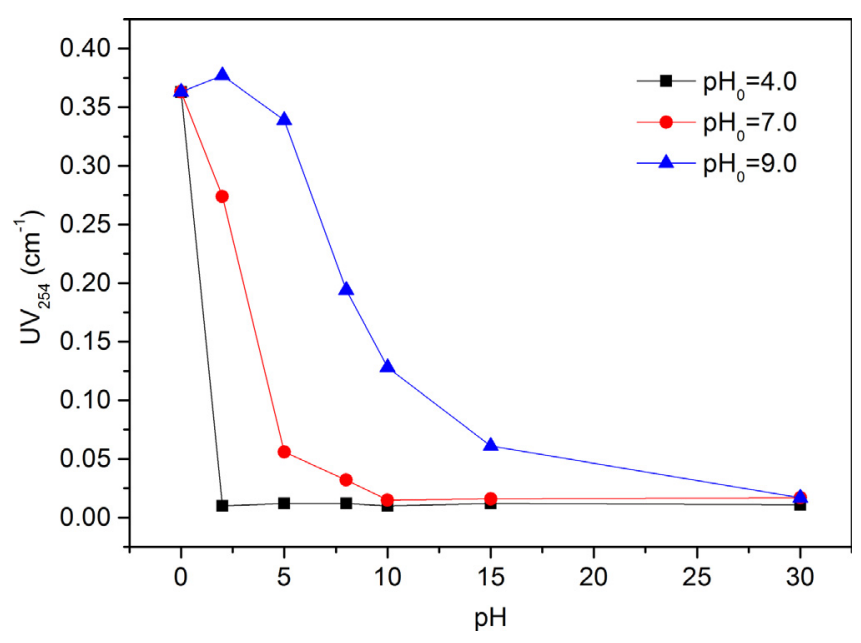

Fig. 7. HA removal by adsorption on preformed EC flocs generated at various initia $\mathrm{pH}$ conditions.

removal at various $\mathrm{pH}$ conditions showed a rapid decrease in the first $10 \mathrm{~min}$, and then kept stable at about $0.025 \mathrm{~cm}^{-1}$ except a little rise of $\mathrm{pH}_{0}=4.0$ (Fig. $6 \mathrm{~b}$ ). EC process at weak acidic range presented a highest efficiency on HA removal among the examined $\mathrm{pH}$ conditions. The results was consistent with the neutralization ability magnitude of $\mathrm{Al}$ hydrolyzes in different $\mathrm{pH}$ conditions. The surface charge of flocs formed from $\mathrm{pH}_{0} 4.0$ firstly reached ZPN (Fig. $1 \mathrm{~b}$ ), thus the $\mathrm{UV}_{254}$ removal for $\mathrm{pH}_{0}=4.0$ attained the maximal value within the shortest time. The results of BET analysis implied that the flocs generated at low initial $\mathrm{pH}$ may have more surface adsorption sites, which would make EC perform better at low $\mathrm{pH}$ condition. Moreover, in-situ $\mathrm{Al}_{13}$ polymer could be generated in EC process, and became the dominant species at about $5 \mathrm{~min}$ in the weak acidic $\mathrm{pH}$ condition [23]. The flocs generated from $\mathrm{Al}_{13}$ polymer showed a larger flocs size and a rougher surface structure than other Al species [21]. It has been suggested that adsorption onto $\mathrm{Al}$ hydroxide precipitates is an important pathway for the removal of NOM [34], and the extent of adsorption depends on the flocs structure and morphology, which was proved by the results of Fig. 7. HA adsorption by the flocs generated from EC at different $\mathrm{pH}$ conditions followed the following order: $\mathrm{pH}_{0} 4>\mathrm{pH}_{0}$ $7>\mathrm{pH}_{0}$ 9. It was consistent with the magnitude of BET surface area. Similar trends were observed in HA removal by EC process (Fig. 6b) and by adsorption on preformed EC flocs (Fig. 7). It indicated that adsorption onto $\mathrm{Al}$ hydroxide flocs played a more important role in HA removal by EC process.

\section{Conclusion}

Water $\mathrm{pH}$ and applied $j$ are most important parameters during EC process to influence the characteristics of flocs structure and morphology, and then determine EC efficiency in pollutants removal. Higher $j$ resulted in a larger flocs size and a faster growth rate, while higher water $\mathrm{pH}$ led to a larger flocs size but a slower growth rate especially in the primary period of EC process. The EC time to form the largest flocs was consistent with that to reach $\mathrm{ZPC}$, where surface charge favors the aggregation of $\mathrm{Al}(\mathrm{OH})_{3}$ precursors to form large flocs. Flocs strength was positively correlated with applied $j$ and negatively correlated with water $\mathrm{pH}$. The flocs generated with low applied $j$ and at low initial $\mathrm{pH}$ had a higher value of BET surface area and a more porous surface structure. Higher $j$ performed better on HA removal due to a larger Al dosage. A highest efficiency in HA removal by EC process occurred at weak acidic range, where the flocs presented a stronger adsorption ability.

\section{Acknowledgements}

The authors are grateful for financial support from the National Natural Science Foundation of China (Nos. 51378490 and 51225805), and the Major Science and Technology Program for Water Pollution Control and Treatment (2015ZX07402003).

\section{References}

[1] P.K. Holt, G.W. Barton, C.A. Mitchell, The future for electrocoagulation as a localised water treatment technology, Chemosphere 59 (2005) 355-367.

[2] M.M. Emamjomeh, M. Sivakumar, Review of pollutants removed by electrocoagulation and electrocoagulation/flotation processes, J. Environ. Manage. 90 (2009) 1663-1679.

[3] S.Y. Lee, G.A. Gagnon, Review of the factors relevant to the design and operation of an electrocoagulation system for wastewater treatment, Environ. Rev. 22 (2014) 421-429.

[4] O. Sahu, B. Mazumdar, P. Chaudhari, Treatment of wastewater by electrocoagulation: a review, Environ. Sci. Pollut. Res. Int. 21 (2014) 23972413.

[5] P. Song, Z. Yang, H. Xu, J. Huang, X. Yang, L. Wang, Investigation of influencing factors and mechanism of antimony and arsenic removal by electrocoagulation using Fe-Al electrodes, Ind. Eng. Chem. Res. 53 (2014) 12911-12919.

[6] E. Bazrafshan, L. Mohammadi, A. Ansari-Moghaddam, A.H. Mahvi, Heavy metals removal from aqueous environments by electrocoagulation process-a systematic review, J. Environ. Health Sci. Eng. 13 (2015) 1.

[7] T.S. Anantha Singh, S.T. Ramesh, New trends in electrocoagulation for the removal of dyes from wastewater: a review, Environ. Eng. Sci. 30 (2013) 333349.

[8] V. Khandegar, A.K. Saroha, Electrocoagulation for the treatment of textile industry effluent-a review, J. Environ. Manage. 128 (2013) 949-963.

[9] A.S. Fajardo, R.C. Martins, R.M. Quinta-Ferreira, Treatment of a synthetic phenolic mixture by electrocoagulation using $\mathrm{Al}, \mathrm{Cu}, \mathrm{Fe}, \mathrm{Pb}$, and $\mathrm{Zn}$ as anode materials, Ind. Eng. Chem. Res. 53 (2014) 18339-18345.

[10] H. Zhao, B. Zhao, W. Yang, T. Li, Effects of Ca2+ and Mg2+ on defluoridation in the electrocoagulation process, Environ. Sci. Technol. 44 (2010) 9112-9116.

[11] M. Solak, M. Kılıç, Y. Hüseyin, A. Şencan, Removal of suspended solids and turbidity from marble processing wastewaters by electrocoagulation: comparison of electrode materials and electrode connection systems, J. Hazard. Mater. 172 (2009) 345-352.

[12] K. Sadeddin, A. Naser, A. Firas, Removal of turbidity and suspended solids by electro-coagulation to improve feed water quality of reverse osmosis plant, Desalination 268 (2011) 204-207.

[13] W.Z. Yu, J. Gregory, L. Campos, Breakage and regrowth of Al-humic flocs-effect of additional coagulant dosage, Environ. Sci. Technol. 44 (2010) 6371-6376.

[14] H. Rong, B. Gao, M. Dong, Y. Zhao, S. Sun, Q. Yue, Q. Li, Characterization of size, strength and structure of aluminum-polymer dual-coagulant flocs under different pH and hydraulic conditions, J. Hazard. Mater. 252 (2013) 330-337.

[15] T. Harif, M. Khai, A. Adin, Electrocoagulation versus chemical coagulation: coagulation/flocculation mechanisms and resulting floc characteristics, Water Res. 46 (2012) 3177-3188.

[16] M.Y.A. Mollah, J.A. Gomes, K.K. Das, D.L. Cocke, Electrochemical treatment of Orange II dye solution-use of aluminum sacrificial electrodes and floc characterization, J. Hazard. Mater. 174 (2010) 851-858.

[17] F. Ulu, S. Barışçı, M. Kobya, H. Särkkä, M. Sillanpää, Removal of humic substances by electrocoagulation (EC) process and characterization of floc size growth mechanism under optimum conditions, Sep. Purif. Technol. 133 (2014) 246-253.

[18] H. Zhao, H. Liu, J. Qu, Effect of pH on the aluminum salts hydrolysis during coagulation process: formation and decomposition of polymeric aluminum species, J. Colloid Interface Sci. 330 (2009) 105-112.

[19] H.Z. Zhao, C. Liu, Y. Xu, J.-R. Ni, High-concentration polyaluminum chloride: preparation and effects of the Al concentration on the distribution and transformation of Al species, Chem. Eng. J. 155 (2009) 528-533.

[20] W. Xu, B. Gao, Q. Yue, Q. Wang, Effect of preformed and non-preformed $\mathrm{Al}_{13}$ species on evolution of floc size, strength and fractal nature of humic acid flocs in coagulation process, Sep. Purif. Technol. 78 (2011) 83-90.

[21] C. Hu, G. Chen, H. Liu, H. Zhao, J. Qu, Characterization of flocs generated by preformed and in situ formed $\mathrm{Al}_{13}$ polymer, Chem. Eng. J. 197 (2012) 10-15.

[22] Z. Zhu, T. Li, J. Lu, D. Wang, C. Yao, Characterization of kaolin flocs formed by polyacrylamide as flocculation aids, Int. J. Miner. Process. 91 (2009) 94-99.

[23] C. Hu, S. Wang, J. Sun, H. Liu, J. Qu, An effective method for improving electrocoagulation process: optimization of $\mathrm{Al}_{13}$ polymer formation, Colloids Surf. A 489 (2016) 234-240.

[24] C. Hu, H. Liu, J. Qu, D. Wang, J. Ru, Coagulation behavior of aluminum salts in eutrophic water: significance of $\mathrm{Al}_{13}$ species and $\mathrm{pH}$ control, Environ. Sci. Technol. 40 (2006) 325-331. 
[25] H. Zhao, J. Peng, S. Lin, Y. Zhang, Covalently bound organic silicate aluminum hybrid coagulants: preparation, characterization, and coagulation behavior, Environ. Sci. Technol. 43 (2009) 2041-2046.

[26] J.L. Lin, C.-J.M. Chin, C. Huang, J.R. Pan, D. Wang, Coagulation behavior of $\mathrm{Al}_{13}$ aggregates, Water Res. 42 (2008) 4281-4290.

[27] G. Sposito, The Environmental Chemistry of Aluminum, CRC Press, 1995.

[28] Z.K. Chowdhury, G.L. Amy, R.C. Bales, Coagulation of submicron colloids in water treatment by incorporation into aluminum hydroxide floc, Environ. Sci. Technol. 25 (1991) 1766-1773.

[29] U. Nowostawska, S.G. Sander, K.M. McGrath, K.A. Hunter, Effects of coagulants on the surface forces of colloidal alumina under water treatment conditions, Colloids Surf. A 266 (2005) 214-222.
[30] M.A. Yukselen, J. Gregory, Breakage and re-formation of alum flocs, Environ. Eng. Sci. 19 (2002) 229-236.

[31] M.A. Yukselen, J. Gregory, The reversibility of floc breakage, Int. J. Miner Process. 73 (2004) 251-259.

[32] P. Jarvis, B. Jefferson, S.A. Parsons, Breakage, regrowth, and fractal nature of natural organic matter flocs, Environ. Sci. Technol. 39 (2005) 2307-2314.

[33] J. Duan, J. Gregory, Coagulation by hydrolysing metal salts, Adv. Colloid Interface Sci. 100 (2003) 475-502.

[34] T.R. Hundt, C.R. O’Melia, Aluminum-fulvic acid interactions: mechanisms and applications, J. Am. Water Works Assoc. (1988) 176-186. 